\title{
EFEKTIVITAS PENGGUNAAN GOOGLE CLASSROOM TERHADAP KUALITAS PEMBELAJARAN DAN HASIL BELAJAR
}

\author{
Kiky Rizky Nova Wardani ${ }^{1 *}$, Ratno Jamalludin ${ }^{2}$ \\ Program Studi Sistem Informasi, Universitas Bina Darma, Palembang ${ }^{1}$ \\ SMK Negeri 1 Indralaya Selatan ${ }^{2}$ \\ e-mail: kikyrizkynovawardani@binadarma.ac.id ${ }^{1}$, ratnojamalludin@gmail.com²
}

\begin{abstract}
Abstrak
Kondisi global saat ini yaitu dengan adanya pandemic covid 19 menyebabkan pembelajaran di lingkungan sekolah dialihkan kepembelajaran daring, salah satunya dengan memanfaatkan google classroom sebagai media pembelajaran. Adapun Tujuan dari penelitian ini adalah mengetahui efektivitas pengaruh penggunaan aplikasi google classroom dan google form terhadap kualitas pembelajaran dan hasil belajar siswa SMK Negeri 1 Indralaya Selatan kelas X (Sepuluh). Penelitian ini menggunakan metode penelitian kuantitatif deskriptif yang dalam peneltian ini menggunakan analisis regresi linear berganda dan regresi logistic ordinal dengan jumlah populasi berjumlah 360 siswa. Teknik purposive sampling digunakan dalam menentukan sampel penilitian sehingga didapatkan jumlah 60 siswa sebagai sampel. Sedangkan untuk pengumpulan data menggunakan tes objectif, wawancara, kuesioner, Pengamatan dan dokumentasi. Hasil penelitian yang telah dilakukan menyatakan bahwa: (1) terdapat efektivitas pengaruh positif yang sangat signifikan dalam penggunaan google classroom terhadap kualitas pembelajaran siswa pada mata pelajaran penjaskes kelas Xa dan Xb di SMK N 1 Indralaya Selatan dengan nilai $t$ hitung $>\mathrm{t}$ tabel $(2.357>2.045)$ dan nilai signifikansi 0.025 . Artinya penggunaan google classroom dapat meningkatkan kualitas pembelajaran siswa pada mata pelajaran penjaskes kelas X di SMK N1 Indralaya Selatan. (2) terdapat pengaruh positif signifikan penggunaan google classroom terhadap hasil belajar siswa pada mata pelajaran penjaskes kelas X di SMK N1 Indralaya Selatan sebesar e $0.892=2.44$ kali dengan signifikansi 0.016 . Artinya penggunaan aplikasi google classroom memiliki pengaruh signifikan sebesar 2.44 terhadap hasil belajar siswa.
\end{abstract}

Kata kunci : Aplikasi Google Classroom; Kualitas pembelajaran; Hasil Belajar

\begin{abstract}
The current global condition, namely the covid 19 pandemic, has caused learning in the school environment to be transferred to online learning, one of which is by utilizing google classrooms as a learning medium. The purpose of this study was to determine the effectiveness of the effect of using the google classroom and google form applications on the quality of learning and learning outcomes of class X(Ten) students of SMK Negeri 1 Indralaya Selatan. This study uses descriptive quantitative research methods in this study using multiple linear regression analysis and logistic ordinal regression with a total population of 360 students. Purposive sampling technique was used in determining the research sample in order to obtain a total of 60 students as the sample. Meanwhile, for data collection using objective tests, interviews, questionnaires, observation and documentation. The results of the research that have been carried out state that: (1) there is a very significant positive effect on the use of google classroom on the quality of student learning in physical education subjects in class Xa and Xb at SMKN 1 Indralaya Selatan with $t$ count $>$ t table $(2.357>2.045)$ and a significance value of 0.025. This means that the use of google classroom can improve the quality of student learning in class $X$ physical education subjects at SMK N1 Indralaya Selatan. (2) there is a significant positive effect of using google classroom on student learning outcomes in the class X physical education subject at SMK N1 Indralaya Selatan of e $0.892=2.44$ times with a significance of 0.016. This means that the use of the google classroom application has a significant effect of 2.44 on student learning outcomes. Keywords : Google Classroom Application; uality of learning; Learning Outcomes; physical education
\end{abstract}


I PENDAHULUAN

World Health Organization (WHO) pada tanggal 11 maret 2020 telah telah mendeklarasikan kejadian pandemi covid 19 sebagai pandemi global [1]. Covid-19 terdeteksi pertama kali berasal dari Wuhan, yang tidak membutuhkan waktu lama telah menyebar dengan cepat ke seluruh dunia. Penyebaran virus yang melanda di seluruh dunia termasuk Indonesia. Sebanyak 213 negara telah terjangkit Covid-19 (sesuai data who Pada tanggal 24 April 2020) diamana hamper 2,7 juta terjangkit positif, dan 190 ribu meninggal dunia [2].

Covid-19 merupakan penyakit menular yang proses penyebarannya secara langsung maupun tidak langsung dari satu orang ke orang lain. Covid 19 ini menyerang sistem pernapasan seperti hidung, tenggorokan, dan paru-paru. Proses penanganan Covid-19 masih belum optimal, vaksin yang baru ditemukan masih tahap penyebaran ke setiap masyarakat yang membutuhkan. Akan tetapi untuk jenis obatobatan belum ada dan masih dalam tahap uji coba. Pemerintah telah menerapkan peraturan dan kebijakan ketat untuk memutus rantai penyebaran Covid-19 ditengah masnayarakat, hal tersebut mengharuskan kita untuk melakukan physical distancing secara mandiri di rumah

Keputusan pemerintah untuk mewajibkan siswa belajar dirumah membuat resah banyak pihak. Kebijakan WFH tertuang dalam Surat Edaran Menteri Pendayagunaan Aparatur Negara dan Reformasi Birokrasi (PAN \& RB) Nomor 50/2020 tentang Perubahan Kedua atas Surat Edaran Menteri PAN \& RB Nomor 19/2020 tentang Penyesuaian Sistem Kerja Aparatur Sipil Negara dalam Upaya Pencegahan Penyebaran Covid-19 di Lingkungan Instansi Pemerintah. Sebagai ASN, guru dalam upaya melaksanakan proses pembelajaran perlu dilakukan secara online atau dalam jaringan (daring). Data dari
UNESCO menjelaskan sebanyak 39 negara telah menerapkan penutupan sekolah dan membatasi segala kegiatan pembelajaran di sekolah yaitu dengan melakukan pembelajaran secara daring/ WFH[3]. SMK Negeri 1 Indralaya Selatan telah melakukan tindakan cepat dan tepat dalam melindungi seluruh siswa, guru dan karyawan dari penularan atau infeksi virus, hal ini berdasarkan Surat Edaran Nomor : 420/3964/SMA.1/Disdik.SS/2020 yang diedarkan oleh Plt Kadisdik Sumsel, Riza Fahlevi pada bulan april 2020 tentang Antisipasi Penyebaran Virus Corona.

Pembelajaran dirumah dilakukan secara online/daring dengan menggunakan menggunakan e-learning. Berdasarkan penelitian yang dilakukan oleh Hanum pada tahun 2013, menyampaikan bahwa elearning merupakan cara baru pembelajaran dengan akses internet untuk meningkatkan lingkungan belajar tanpa harus dating ke ruangan kelas, dapat diaskes dimana saja dan kapan saja selama memiliki jaringan internet [4]. SMK Negeri 1 Indralaya selatan telah menerapkan selama pendemi Covid-19 kepada guru dan siswa untuk menggunakan elearning sebagai media pembelajaran, salah satu penerapan e-learning adalah menggunakan aplikasi google classroom dan google form yang dapat menunjang proses pembelajaran. Untuk dapat membantu guru sebagai pengajar dalam memberikan pembelajaran (Materi, tugas dan diskusi) secara online kepada siswa digunakan Aplikasi google classroom dan aplikasi google form (Ujian). Google classroom merupakan sebuah aplikasi yang disediakan google dan dirancang untuk mempermudah interaksi antara guru dan siswa dalam setiap proses belajar mengajar [5].

Terdapat beberapa fitur yang dapat digunakan di dalam Aplikasi Google classroom untuk menunjang proses belajar mengajar, salah satunya Halaman utama yang berfungsi sebagai tempat untuk 
melampikan materi, tugas maupun diskusi. Fitur-fitur yang terdapat di aplikasi google classroom dapat dimanfaatkan dengan baik oleh para guru untuk mengupload pelajaran. Sehingga dapat dikatakan Aplikasi ini sebagai salah satu media pembelajaran yang sangat mudah untuk dipahami dan dipelajari karena aplikasi ini dapat melibatkan siswa secara maksimal dalam mencari, memahami, menyelidiki, menganalisis dan merumuskan hasil belajar.[6] Fitur lain yang digunakan oleh para pengajar adalah Membuat tugas. Bahkan membuat topic untuk materi pun sangat mudah dan fitur yang menarik sehingga dapat digunakan untuk membuat topik pelajaran yang akan dibahas disetiap pertemuannya [7].

Penggunaan aplikasi google classroom pada mata pelajaran pelajaran penjaskes memadukan dengan google form (untuk ujian) whatsapp group (untuk info dan pengumuman, Link youtube dan Tiktok

Beberapa Halamn tampilan aplikasi google classroom dapat dilihat pada gambar dibawah ini :

1. Tampilan Halaman dari web dan Hp Aplikasi google classroom.
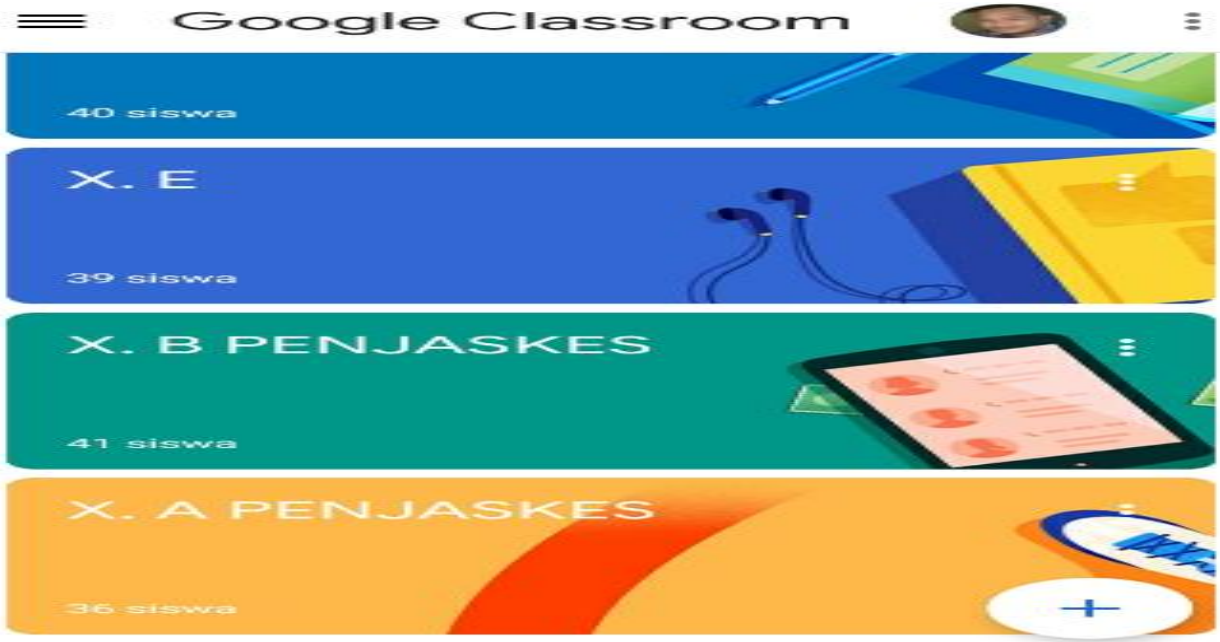

Gambar 1 Tampilan Halaman google classroom melai web dan hp Sumber data : Google Classroom

2. Halaman google classroom pada mata pelajaran penjaskes

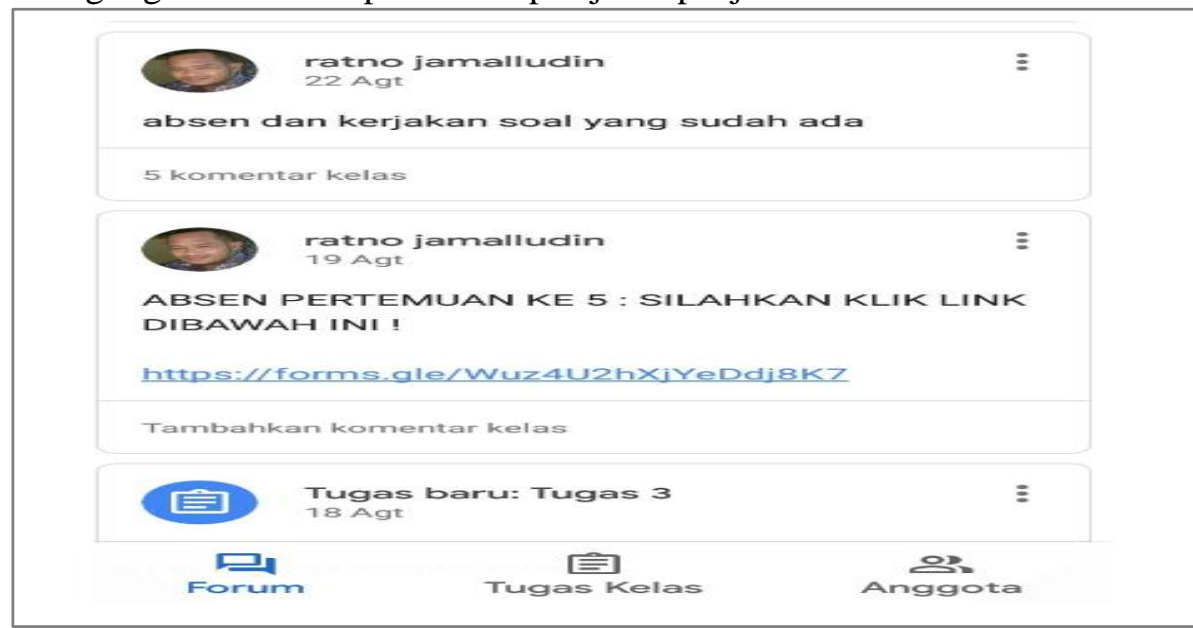

Gambar 2 Tampilan halaman google classroom pada mata pelajaran penjaskes Sumber data : Google classroom 
3. Tampilan materi, tugas dan forum pada mata pelajaran penjaskes

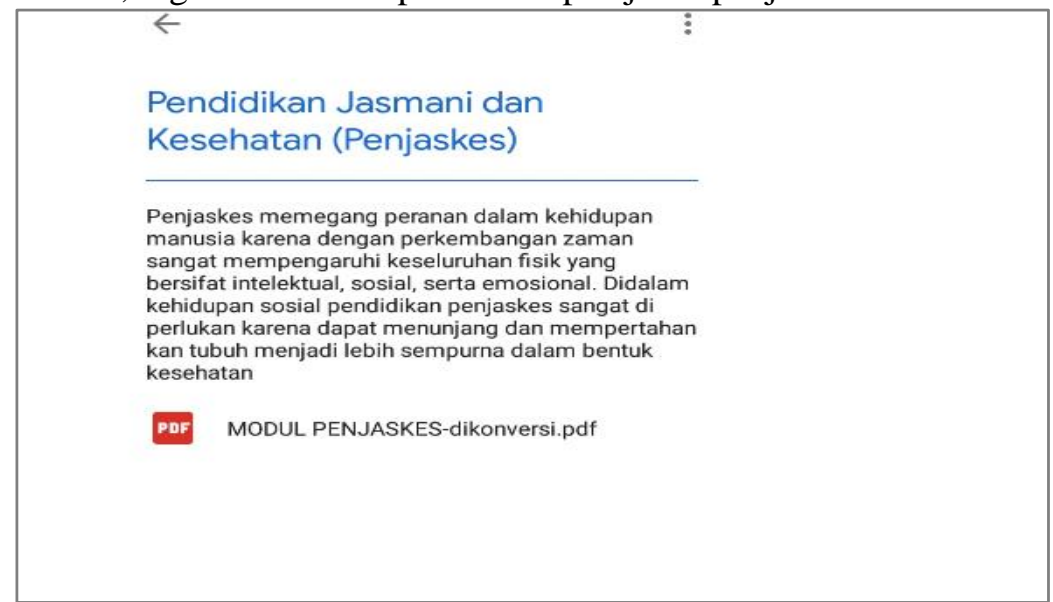

Gambar 3 Tampilan halaman google classroom pada materi, tugs dan forum mata pelajaran penjaskes

Sumber data : Google classroom

Pengoptimalan fitur Aplikasi google classroom tentunya berdampak positif bagi prose belajar dan mengajar saat ini diantaranya adalah tidak terbatas oleh ruang dan waktu, materi pembelajaran yang dibutuhkan lebih mudah untuk diakses, serta mampu melatih keterampilan siswa dan guru dalam mengolah data dan keterampilan dalam menggunakan teknologi. Sehingga dapat menjadikan Aplikasi Google classroom sebagai media pembelajaran yang interaktif serta dapat menunjang proses pembelajaran daring/offline/jarak jauh serca efektif dan efisien.[8]

Pandemi covid-19 telah berpengaruh terhadap semua tingkatan dalam sistem pendidikan di Indonesia, dimulai dari tingkat dasar sampai perguruan tinggi. Namun, pelaksanaan proses pembelajaran secara online memiliki beberapa kendala. Salah satu kendala terberat dalam pembelajaran daring adalah mengajar mata pelajaran penjaskes.Oleh karena itu penelitian ini dilakukan di mata pelajaran Penjaskes Kelas X.a dan X.b di SMK Negeri 1 Indralaya Selatan sebagai objek penelitian untuk melihat efektivitas penggunaan aplikasi google classroom terhadap kualitas pembelajaran dan hasi belajar siswa pada mata pelajaran penjaskes. Dengan kondisi
WFO diharapkan siswa tetap dapat mengikuti pemlajaran penjaskes dan dapat mencapai KKM sebesar 7.5. Namun berdasarkan hasil pengamatan yang telah dilakukan oleh peneliti, Selama proses kegiatan belajar mengajar menggunakan aplikasi google classroom masih belum maksimal. Banyak hal yang bisa menjadi penyebab kurangnya minat siswa dalam menggunakan aplikasi google classroom seperti siswa lebih memeilih bermain hp/laptop untuk dapat digunakan bermain game, Guru tidak aktif atau tidak berinteraksi dengan siswa, minimnya penggunaan interaksi yang interaktif membuat siswa menjadi tidak antusias dalam proses pembelajaran. hal ini dapat menjadikan siswa kesulitan dalam memahami mata pelajar penjaskes yang kemudian berdampak pada rendahnya hasil belajar siswa. Tidak hanya dari sisi guru saja, rendahnya hasil belajar dapat dilihat dari sisi siswa, seperti siswa terlalau banyak menggunakan hp untuk hal lain, seperti menonton, media social sehingga tentu akan menurun hasil belajar siswa tersebut. Berdasarkan uraia diatas maka peneliti tertarik untuk mengadakan penelitian dengan judul "Efektivitas Penggunaan Classroom Terhadap Kualitas Pembelajaran 
dan Hasil Belajar Siswa Pada Mata Pelajaran Penjaskes."

\section{TINJAUAN PUSTAKA}

\subsection{Pandemi COVID-19}

Pernyataan yang diumumkan oleh WHO melalui DirJen Tedros Adhanom Ghebreyesus dalam konferensi pers yang berlangsung pada Rabu (11/3/2020) menyatakan bahwa virus Covid-19 tengah merebak saat ini dan menyerang hamper $2 / 3$ negara diseluruh belahan dunia saat ini. Pengumuman yang disampaikan oleh WHO teresbut memaksa Indonesia, Presiden Joko Widodo untuk membuat kebijakan secara cepat dan akurat. Hal ini memaksa seluruh masyarakat Indonesia untuk melakukan Physical distancing tanpa terkecuali. Physical distancing atau yang dikenal dengan Work From Home telah memaksa seluruh masyarakat Indonesia untuk melakukan semua aktivitas didalam rumah. Menindaklanjuti Pengumuman tersebut Menteri Pendidikan dan Kebudayaan juga mengeluarkan beberapa himbauan mengenai pencegahan penyebaran virus corona Covid19 di lingkungan pendidikan dan jajaran Kemendikbud. Dalam surat edaran tersebut Menteri pendidikan dan kebudayaan mendukung adanya kebjiakan pemerintah pusat dalam hal meliburkan aktivitas sekolah dan jajarannya, guna keamanan dan keselamatan siswa dan guru juga jajaran pendidik.[9].

\subsection{Pembelajaran Daring}

Pembelajaran daring merupakan kegiatan belajar mengajar di masa pandemi covid-19 dilaksanakan dengan metode jarak jauh dengan sistem daring (e-learning).[10] Sistem daring dapat didefinisikan sebagai proses pembelajaran digital melalui jaringan internet. Pembelajaran daring dilakukan secara online segala bentuk materi, komunikasi,tes semua disampaikan secara online Pada proses pembelajaran E-
Learning Bahan pelajaran, proses penyampaian dan pengelolaan aktivitas, dapat dilihat dengan baik sehingga dapat diperoleh efektivitas dan efisiensi [11].

\subsection{Aplikasi Google Classroom}

Aplikasi Google Classroom adalah layanan berbasis Internet yang disediakan oleh Google sebagai sebuah sistem elearning. Pelayanan ini didesain dengan sangat simple, karena aplikasi berfungsi untuk memantau pengajar dalam memberikan materi, tugas dan diskusi kepada siswa [11] Pemanfaatan Google Classroom dapat komputer dan dapat melalui telepon genggam/gawai. [12]

Aplikasi google classroom dapat dilihat di situs https://classroom.google.com atau dapat mengunduh di aplikasi melalui playstore maupun app store. Google classroom dirancang untuk mempermudah guru dalam berinteraksi dengan siswa sehingga guru dapat lebih mengeksplorasi gagasan keilmuan yang dimilikinya untuk diberikan kepada siswanya. Waktu yang tidak terbatas memberikan kemudahan kepada guru dalam membagikan materi pelajaran yang tidak hanya teori tapi juga praktik. Aplikasi google classroom pun dilengkapi dengan sarana diskusi. Sehingga siswa dapat melakukan diskusi atau Tanya jawab kepada guru maupun dengan siswa laiinya [11].

\subsection{Google Form}

Google Form merupakan sebuah aplikasi yang digunakan untuk membantu, merencanakan perencanaan, membuat survey ataupun mengumpulkan informasi secara cepat dan akurat. google form pun dapat dihubungkan dengan spreadsheet sehingga tanggapan yang dikirimkan oelh siswa dapat direkam secara jelas dan akurat. Pemanfaatan Google Form dalam bidang pendidikaan antara lain: 1) Memberikan tugas, latihan, ujian secara online, 2) 
Mengumpulkan pendapat hasil diskusi, 3) Mengumpulkan data siswa/guru, 4) Membuat formulir pendaftaran online untuk sekolah, 5) Membagikan kuesioner kepada orang-orang secara online [12].

\subsection{Kualitas Pembelajaran}

Kualitas pembelajaran adalah mengetahui segala aktivitas kegiatan belajar yang dilakukan apakah sudah berjalan dengan sesuai aturan serta menghasilkan luaran sesuai dengan yang diharapkan atau sebaliknya. Agar mendapatkan hasil yang sesuai dengan yang diharapkan tentunya kualitas pembelajaran berkaitan dengan bagaimana mengelola proses belajar, dalam hal ini peran strategis pembelajaran yang dikembangkan di sekolah dapat menghasilkan luaran sesuai dengan apa yang diharapkan. Satu elemen yang sangat krusial dalam pendidikan adalah kualitas pembelajaran. Kualitas pembelajaran dikaitkan dengan proses interaksi komunikas atara guru dan siswa, tentunya proses komunikasi ini mengandung lima hal yaitu kesesuaian, bermutu, Efektivitas ,Efisiensi dan Produktivitas [13].

\subsection{Hasil Belajar}

Setelah memberikan kualitas pembelajaran yang baik kepada siswa yang menjadi tujuan selanjutnya adalah mendapatkan hasil belajar sesuai dengan yang diharapkan [14]. Hasil belajar merupakan sebuah realisasi dari hasil yang dimiliki seseorang. Penguasaan hasil belajar oleh seseorang dapat dilihat dari perilakukanya, baik perilaku dalam bentuk penguasaan pengetahuan, keterampilan berpikir maupun keterampilan motoric [15] Dari makna diatas dapat disimpulkan hasil belajar adalah perolehan dari proses belajar siswa yang dapat ditunjukkan dengan angka dan huruf [16].

\subsection{Hipotesis Penelitian}

H1 : Terdapat efektivitas pengaruh penggunaan aplikasi Classroom terhadap kualitas pembelajaran pada mata pelajaran Penjaskes kelas Xa dan $\mathrm{Xb}$ di SMK N 1 Indralaya Selatan

H2 : Terdapat Efektivitas pengaruh penggunaan Aplikasi Google Classroom terhadap Hasil Belajar pada mata pelajaran Penjaskes kelas Xa dan Xb di SMK N 1 Indralaya Selatan

\section{METODOLOGI PENELITIAN}

\subsection{Kerangka Pemikiran}

Berdasarkan pengembangan hipotesa, maka dapat disusun kerangka pemikiran yang menggambarkan hubungan antara variabel dependen dan variabel independen yang akan diuji. Adapun kerangka pemikiran nya sebagai berikut :

Rancangan hiptesa penelitian yang diajulan adalah sebagai berikut :

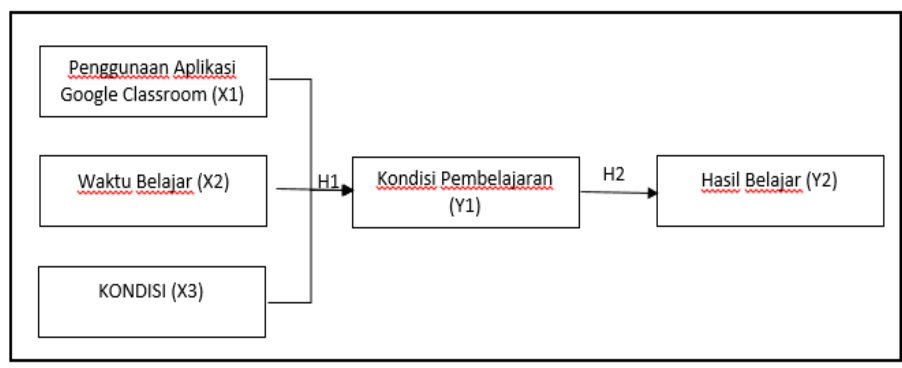

Gambar 4 Rancangan Hipotesa yang diajukan

Sumber : data diolah oleh penulis.

\subsection{Populasi dan Sampel Penelitian}

Populasi pada penelitian ini adalah siswa kelas X SMK Negeri 1 Indralaya Selatan yang berjumlah 360 siswa. Proses pengambilan sampel menggunakan nonprobabilty sampling. Teknik ini dipilih didasarkan pada tujuan yang dicapai oleh peneliti yaitu dalam pemilihan kelompok kelas, peneliti memilih sampel kelompok atau kelas dari populasi yang menjadi objek penelitian ini yaitu : 
Tabel 1 Populasi dan sampel Penelitian

\begin{tabular}{|c|c|c|c|c|}
\hline No & Populasi & $\begin{array}{c}\text { Jumlah } \\
\text { Kelas }\end{array}$ & Sampel & $\begin{array}{c}\text { Jumlah } \\
\text { Siswa }\end{array}$ \\
\hline 1 & Kelas X & $\begin{array}{l}10 \\
\text { Kelas }\end{array}$ & $\mathrm{Xa}$ & 30 \\
\hline & & & $\mathrm{Xb}$ & 33 \\
\hline
\end{tabular}

Sumber : data diolah oleh penulis.

\subsection{Metode Pengumpulan Data}

Adapun teknik pengumpulan data dalam penelitian ini dilakukan dengan cara:

1. Metode Tes adalah suatu prosedur yang spesifik dan sistematis untuk mengukur tingkah laku seseorang sehingga tingkah laku tersebut dapat digambarkan dengan bantuan angka, skala atau dengan sistem kategori, Medote ini digunakan untuk mengetahui kemampuan itelegensi, minat dan bakat seseorang. Dalam penelitian ini metode tes digunakan untuk mengetahui minat dan bakat siswa dalam pelajaran penjaskes [17].

2. Pengamatan diartikan sebagai sebuah kegiatan mengamati objek secara langsung [18] Proses pengamatan pada penelitian ini dengan cara mengamati secara langsung interaksi siswa dan guru. Pada penelitian ini pengamatan dilakukan sebanyak 6 kali pertemuan. Yaitu pada pertemuan 1, 5, 8, 10, 11 dan 18.

3. Interview atau Wawancara dapat diartikan sebagai suatu teknik pengumpulan data yang bertujuan untuk melakukan pendalaman terhadap permasalahan yang ingin diteliti secara mendalam" [18]. Proses wawancara dalam penelitian ini dilakukan dengan cara semi terstruktur. Peneliti merumuskan dahulu pertanyaan yang akan diberikan. Wawancara ini dilakukan pada guru mata pelajarandan beberapa siswa sebagai perwakilan.

4. Angket atau Kuesioner Tujuan menggunakan kuesioner adalah untuk mengetahui dan mencari informasi yang dibutuhkan mengenai suatu masalah dari responden tanpa khawatir apabila responden memberikan jawaban yang tidak sesuai [18] Proses Pengukuran menggunakan skala Likert, yaitu tingkatan preferensi atas jawaban dengan pilihan sebagai berikut:[19]

Tabel 2 Kategori Skala Likert

\begin{tabular}{|c|l|}
\hline Nilai & Tingkatan \\
\hline 1 & Sangat Tidak Setuju \\
\hline 2 & Tidak Setuju \\
\hline 3 & Ragu-ragu/Netral \\
\hline 4 & Setuju \\
\hline 5 & Sangat Setuju \\
\hline
\end{tabular}

Sumber dara : I.Ghozali [19]

Adapun kuesioner yang digunakan yaitu kuesioner tertutup. Kuesioner alan diberikan kepada siswa dan guru penjaskes setelah pembelajaran selesai dilaksanakan. Adapun objek penyebaran adalah seluruh guru penjaskes dan siswa kelas $\mathrm{Xa}$ dan $\mathrm{Xb}$ SMK Negeri 1 Indralaya Selatan degan menggunakan fasilitas google form.

5. Dokumentasi merupakan catatan peristiwa yang sudah berlalu. Dalam bentuk tulisan, gambar, atau karyakarya [20]. Dengan dokumentasi diharapkan dapat memberi kelengkapan data dalam penelitian yang dilakukan di SMK Negeri 1 Indralaya Selatan. Adapun dokumentasi yanag dibutuhkan yaitu data guru penjaskes, data siswa kelas X.a dan X.b, alat dan prasarana yang menunjang pelajaran penjaskes.

\subsection{Metode Penelitian}

Metode Penelitian dalam penelitian ini adalah metode kualitatif desktriptif, data dari penelitian bersifat kuantitatif atau statistik, dan data yang dihasilkan akan dianalisis dan diuji hipotesis yang telah ditetapkan.[20] Dalam penelitian ini menggunakan analisis regresi linear berganda dan regresi logistik ordinal yang didasarkan atas hubungan fungsional maupun kausal antara variabel independen dengan variabel dependen. 
3.5 Teknik Analiss dan pengolahan data

1. Uji coba instrument

a. Uji validitas : Uji ini digunakan untuk pengujian intrumen tes dan angket. Uji validitas pada instrumen tes dan angket ini menggunakan korelasi product moment pearson dengan menggunakan rumus sebagai berikut :

$r_{x y}$

$=\frac{n\left(\sum x y\right)-\left(\sum x\right)\left(\sum y\right)}{\left.\sqrt{\left(n\left(\sum x^{2}\right)\right.}-\left(\sum x\right)^{2}\right)\left(n\left(\sum y^{2}\right)-\left(\sum y\right)^{2}\right)}$

\section{Keterangan:}

$\mathrm{r}:$ Koefisien korelasi

$\mathrm{n}$ : Banyak siswa

$X$ : Skor tiap butir soal

Y : Skor total yang diperoleh siswa

$\sum \mathrm{x}$ : Jumlah skor untuk tiap butir soal

$\sum$ y: Jumlah skor total

Tabel 3 Kategori Validitas Instrumen

\begin{tabular}{|l|l|}
\hline $\begin{array}{l}\text { Kategori } \\
\text { Validitas }\end{array}$ & Keterangan \\
\hline $0,00-0,20$ & Sangat rendah \\
\hline $0,20-0,40$ & Rendah \\
\hline $0,40-0,60$ & Cukup \\
\hline $0,60-0,80$ & Tinggi \\
\hline $0,80-1,00$ & Sangat tinggi \\
\hline
\end{tabular}

Sumber data : Sugiyono [20]

b. Uji reabilitas : Salah satu nilai ukur reliabilitas yang paling sering digunakan adalah koefiien Alpha Cronbach. Cara pengukurannya adalah seluruh item pertanyaan yang telah valid dimasukan dan diukur koefisien.[15] Cara pengukurannya adalah seluruh item pertanyaan yang telah valid dimasukan dan diukur koefisien Alpha Cronbach. Jika nilai yang diperoleh lebih besar dari 0,6 maka instrumen tes dan angket tersebut telah reliabel. Uji reliabilitas untuk instrumen menggunakan Alpha Cronbach dengan rumus:

$$
r_{11}=\left(\frac{k}{k-1}\right)\left(1-\frac{\sum a \frac{2}{b}}{v \frac{2}{t}}\right)
$$

Keterangan :

$r_{11}$ : Reliabilitas instrument

$k$ : Banyaknya butir pertanyaan atau banyaknya soal

$\sum a \frac{2}{b}:$ Jumlah varian butir/item

$v \frac{2}{t}$ : Variasn skor total

Besarnya reliabilitas dikategorikan seperti tabel berikut :

Tabel 4 Kategori Reliabilitas Instrumen

\begin{tabular}{|l|l|}
\hline $\begin{array}{l}\text { Nilai kategori } \\
\text { relaibilitas } \boldsymbol{r}_{\mathbf{1 1}}\end{array}$ & Keterangan \\
\hline $0,00-0,20$ & Sangat rendah \\
\hline $0,20-0,40$ & Rendah \\
\hline $0,40-0,60$ & Cukup \\
\hline $0,60-0,80$ & Tinggi \\
\hline $0,80-1,00$ & Sangat tinggi \\
\hline
\end{tabular}

Sumber data : Thoifah [15]

\section{Statistik Deskriptif}

Statistik deskriptif digunakan untuk menganalisis data yang dihasilkan oleh kuesioner dengan cara menggambarkan data yang telah dikumpulkan. gambaran suatu data yang dilihat dari nilai rata-rata (mean), Standar deviasi, varian, maksimum, minimum, sum, range, kurtosis, dan skewness.[19]

\section{Uji prasayarat Analisis Data}

a. Uji asumsi klasik

1) Uji Normalitas :Bertujuan untuk menguji apakah dalam model regresi, variabel pengganggu atau residual memiliki distribusi normal. Ada dua cara untuk mendeteksi apakah residual berdistribusi normal atau tidak dengan analisis grafik dan uji statistik".

2) Uji Multikolonieritas : bertujuan untuk menguji apakah nilai model regresi ditemukan adanya kolerasi antar variabel bebas (independen) atau tidak. Model regresi yang benar seharusnya tidak terjadi 
kolerasi di antara variabel independen.

3) Uji Heteroskedastisitas : bertujuan untuk menguji apakah dalam nilai model regresi terjadi ketidaksamaan variasi dari residual satu pengamatan ke pengamatan lain. Untuk mendeteksi ada atau tidaknya heteroskedastisitas dilakukan dengan cara melihat garfik plot antara nilai prediksi variabel terikat dan melakukan Uji Glejser.

\section{Uji Hipotesis}

Uji Hipotesis Regresi Analisis Data dalam penelitian ini :

1. Koefisien Korelasi (R) merupakan suatu alat statistik yang dapat digunakan untuk membandingkan nilai hasil pengukuran dua variabel yang berbeda agar dapat menentukan tingkat hubungan antara variabel-variabel $\mathrm{X} 1, \mathrm{X} 2, \mathrm{X} 3, \mathrm{Y} 1, \mathrm{Y} 2$

2. Koefisien Determinasi Adjusted RSquare (Adj R2 ) Koefisien determinasi (R 2 ) pada intinya mengukur seberapa jauh kemampuan model dalam menerangkan variasi variabel dependen.

3. Uji Signifikansi atau yang dikenal dengan $U j i \mathrm{t}$ pada dasarnya $\mathrm{Uji} \mathrm{t}$ merupakan pengujian yang bertujuan untuk mengetahui nilai keofisien regresi signifikan atau tidak significant.

4. Uji F digunakan untuk menunjukan semua variabel independen atau bebas yang dimasukan dalam model mempunyai pengaruh secara bersamasama terhadap variabel dependen.
IV HASIL DAN PEMBAHASAN

4.1 Hasil Uji coba instrument

1. Uji Coba Instrument

a. Uji validitas : Analisa dilakukan dengan cara mengkorelasikan masing-masing skor item dengan skor total Pengujian menggunakan uji dua sisi dengan taraf signifikansi 0,05. Kriteria pengujian adalah sebagai berikut: - Jika $r$ hitung $\geq \mathrm{r}$ tabel (uji 2 sisi dengan sig. 0,05) maka instrumen atau item-item pertanyaan berkorelasi signifikan terhadap skor total (dinyatakan valid). - Jika $r$ hitung $<\mathrm{r}$ tabel (uji 2 sisi dengan sig. 0,05) maka instrumen atau item-item pertanyaan tidak berkorelasi signifikan terhadap skor total (dinyatakan tidak valid). Adapun yang diuji validitasnya :

b. Uji validitas instrument angket. Hasil dari uji validitas intrusmen yang diajukan kepada siswa kelas X.a dan X.B SMK N 1 Indralaya Selatan, dengan jumlah 72 siswa serta 25 angket soal didapat nilai korelasi antara skor item dengan skor total. Nilai perbandingan tersebut kita bandingan dengan nilai $r$ tabel (Nilai $r$ tabel : 0,361). Berikut hasilnya.

Tabel 5 Hasil perhitungan Uji Validitas Instrumen Angket

\begin{tabular}{|l|l|l|l|l|}
\hline Variabel & $\begin{array}{l}\text { No } \\
\text { Soa } \\
1\end{array}$ & $\begin{array}{l}\mathrm{R} \\
\text { Hitung }\end{array}$ & $\begin{array}{l}\mathrm{R} \\
\text { Tabel }\end{array}$ & $\begin{array}{l}\text { Keteranga } \\
\mathrm{n}\end{array}$ \\
\hline $\begin{array}{l}\text { Kualitas Pembelajaran } \\
\left(Y_{\text {Kualitas Pembelajaran }}\right)\end{array}$ & 1 & 0,9259 & 0,361 & Valid \\
\cline { 2 - 5 } & 2 & 0,6009 & 0,361 & Valid \\
\cline { 2 - 5 } & 3 & 0,6378 & 0,361 & Valid \\
\cline { 2 - 5 } & 4 & 0,8582 & 0,361 & Valid \\
\cline { 2 - 5 } & 5 & 0,8582 & 0,361 & Valid \\
\cline { 2 - 5 } & 6 & 0,8313 & 0,361 & Valid \\
\cline { 2 - 5 } & 7 & 0,5117 & 0,361 & Valid \\
\cline { 2 - 5 } & 8 & 0,8918 & 0,361 & Valid \\
\cline { 2 - 5 } & 9 & 0,8496 & 0,361 & Valid \\
\cline { 2 - 5 } & 10 & 0,3039 & 0,361 & Tidak \\
& & & & Valid \\
\cline { 2 - 5 } & 11 & 0,6669 & 0,361 & Valid \\
\cline { 2 - 5 } & 12 & 0,1697 & 0,361 & Tidak \\
& & & & Valid \\
\cline { 2 - 5 } & 13 & 0.7521 & 0,361 & Valid \\
\hline Penggunaan Classroom & 14 & 0,8074 & 0,361 & Valid \\
\cline { 2 - 5 } (X1) & 15 & 0,8338 & 0,361 & Valid \\
\cline { 2 - 5 } & 16 & 0,7881 & 0,361 & Valid \\
\cline { 2 - 5 } & 17 & 0,5525 & 0,361 & Valid \\
\cline { 2 - 5 } & 18 & 0,5478 & 0,361 & Valid \\
\cline { 2 - 5 } & 19 & 0,6058 & 0,361 & Valid \\
\hline
\end{tabular}




\begin{tabular}{|l|l|l|l|l|}
\hline & 20 & 0,7855 & 0,361 & Valid \\
\cline { 2 - 5 } & 21 & 0,8955 & 0,361 & Valid \\
\cline { 2 - 5 } & 22 & 0,9115 & 0,361 & Valid \\
\cline { 2 - 5 } & 23 & 0,5411 & 0,361 & Valid \\
\hline $\begin{array}{l}\text { Waktu Pembelajaran } \\
\text { (X2) }\end{array}$ & 24 & 0,7890 & 0,361 & Valid \\
\hline Kondisi Belajar (X3) & 25 & 0,6789 & 0,361 & Valid \\
\hline
\end{tabular}

Sumber data olahan penulis 2020

Berdasarkan hasil uji validitasi yang didapat dari tabel 5, diperoleh nilai korelasi yaitu 0,361 . Terdapat item 10 dan item 12 memiliki nilai kurang dari $\mathrm{r}$ table yang diajukan yaitu 0.361. Sehingga dapat disimpulkan item 10 dan item 12 tidak berkorelasi significant dengan skor total (0.361) dan dinyatakan tidak valid sehingga harus diperbaiki. Sementara item lainnya dinyatakan valid,

c. Hasil Uji validitas instrument tes. Hasil dari uji validitas yang diajukan ke siswa, dnegan jumlah siswa 72 siswa dan 23 soal . Berikut ini dapat dilihat hasil dari perhitungan validitas untuk keseluruhan butir pertanyaan.

Tabel 6 Hasil uji perhitungan validitas instrument tes

\begin{tabular}{|c|c|c|c|c|}
\hline Variabel & $\begin{array}{l}\text { No } \\
\text { Soal }\end{array}$ & $\begin{array}{l}\mathrm{R} \\
\text { Hitung }\end{array}$ & $\begin{array}{l}\mathrm{R} \\
\text { Tabel }\end{array}$ & Keterangan \\
\hline \multirow{23}{*}{$\begin{array}{lll}\text { Hasil } & \text { Belajar } \quad\left(\mathrm{Y}_{\text {Hasil }}\right. \\
\text { Belajar }\end{array}$} & 1 & 0,5259 & 0,361 & Valid \\
\hline & 2 & 0,4009 & 0,361 & Valid \\
\hline & 3 & 0,6278 & 0,361 & Valid \\
\hline & 4 & 0,5682 & 0,361 & Valid \\
\hline & 5 & 0,7582 & 0,361 & Valid \\
\hline & 6 & 0,6313 & 0,361 & Valid \\
\hline & 7 & 0,5117 & 0,361 & Valid \\
\hline & 8 & 0,7918 & 0,361 & Valid \\
\hline & 9 & 0,7496 & 0,361 & Valid \\
\hline & 10 & 0,5669 & 0,361 & Valid \\
\hline & 11 & 0.4521 & 0,361 & Valid \\
\hline & 12 & 0,7074 & 0,361 & Valid \\
\hline & 13 & 0,6338 & 0,361 & Valid \\
\hline & 14 & 0,7881 & 0,361 & Valid \\
\hline & 15 & 0,5525 & 0,361 & Valid \\
\hline & 16 & 0,4478 & 0,361 & Valid \\
\hline & 17 & 0,7058 & 0,361 & Valid \\
\hline & 18 & 0,2855 & 0,361 & $\begin{array}{l}\text { Tidak } \\
\text { Valid }\end{array}$ \\
\hline & 19 & 0,5955 & 0,361 & Valid \\
\hline & 20 & 0,6115 & 0,361 & Valid \\
\hline & 21 & 0,5411 & 0,361 & Valid \\
\hline & 22 & 0,7890 & 0,361 & Valid \\
\hline & 23 & 0,6789 & 0,361 & Valid \\
\hline
\end{tabular}

Sumber data olahan penulis 2020
Berdasarkan hasil analisis yang didapat dari tabel 6 diperoleh nilai korelasi 0,361 , pada tabel tersebut dapat dilihat item nomor 18 nilainya kurang dari $\mathrm{r}$ table yang berarti item nomor 18 tidak berkolerasi significant dengan skor total / tidak valid. Item nomor 18 harus diperbaiki.

\section{d. Uji Reabilitas}

Uji reliabilitas digunakan untuk mengukur sejauh mana instrument dapat digunakan dan dipercaya. Nilai koefisien Alpha Cronbach dengan taraf signifikansi 0,05 . Adapun hasil uji reliabilitas instrumen angket seperti pada tabel 7

Tabel 7 Uji $\quad$ Reliabilitas $\quad$ Intstrumen Angket

\begin{tabular}{|l|l|l|}
\hline No & Statistik & Skor/Nilai \\
\hline $\mathbf{1}$ & Jumlah Varian item & $\mathbf{8 , 2 7 4}$ \\
\hline $\mathbf{2}$ & Varian total & $\mathbf{1 3 7 , 3}$ \\
\hline $\mathbf{3}$ & Reliabilitas & $\mathbf{0 , 8 6 6 7}$ \\
\hline Kategori & Sangat Tinggi \\
\hline
\end{tabular}

Sumber data olahan penulis 2020

Berdasarkan data tabel 8 dapat disimpuklan nilai perhitunagn reliabilitas berada pada nilai 0,8667 dari 23 item angket, yang berarti adalah nilai tersebut reliable dan dalam kategori sangat tinggi. Sedangkan Uji reliabilitas instrumen tes pada penelitian ini menggunakan koefisien Alpha Cronbach pada taraf signifikansi 0,05 untuk mengukur sejauh mana alat ukur atau instrumen dapat dipercaya dan diandalkan atau reliabel, adapun hasil uji reliabilitas instrumen pada penelitian seperti pada tabel 8 .

Tabel 8 Uji reliabilitas instrument tes

\begin{tabular}{|l|l|l|}
\hline No & Statistik & Skor/Nilai \\
\hline 1 & $\begin{array}{l}\text { Jumlah Varian } \\
\text { item }\end{array}$ & 6,004 \\
\hline 2 & Varian total & 32,75 \\
\hline 3 & Reliabilitas & 0,876 \\
\hline Kategori & Sangat Tinggi \\
\hline
\end{tabular}

Sumber data olahan penulis 2020 
Berdasarkan data tabel 8 dapat disimpulkan nilai perhitungan reliabilitas berada pada nilai 0,876 dari 23 item soal, yang artinya adalah nilai tersebut reliabel dan dalam kategori sangat tinggi

\section{Statistik Deskriptif}

Statistik Deskriptif Statistik deskriptif adalah statistik yang digunakan untuk menganalisis data dengan cara mendeskripsikan atau menggambarkan data yang telah terkumpul[19] adapun hasil yang diperoleh yaitu :

\section{a. Penjabararan Hasil Karakteristik \\ Responden}

Sampel yang menjadi responden dalam penelitian ini sebanyak 60 siswa yang terdiri $48,61 \%$ jenis kelamin perempuan dan 51,39 $\%$ jenis kelamin laki laki.

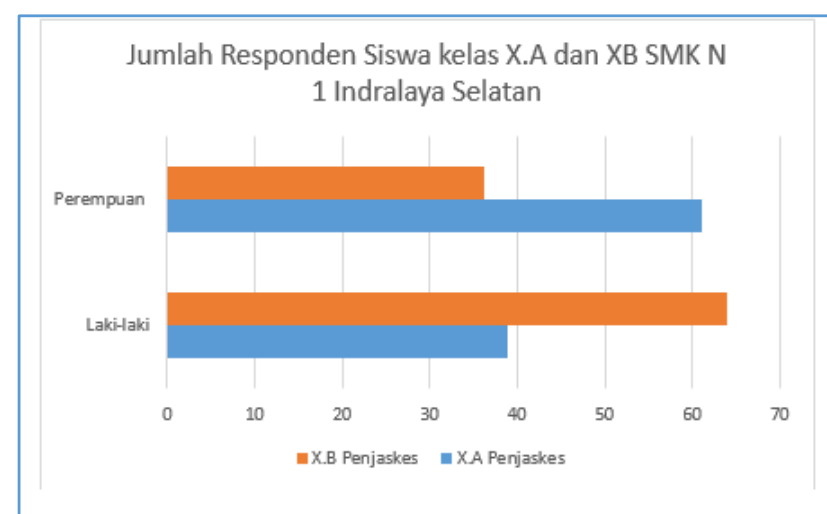

Gambar 5 Karakteristik responden

Sumber data olahan penulis 2020

Proses pembelajaran dikakukan di rumah menyebabkan banyak hal antara lain : responden paling banyak menghabiskan waktu dalam sehari dengan mengerjakan tugas-tugas yang diberikan guru, Aktivitas lainnya bermain handphone/Nonton tv, dan membantu pekerjaan orang tua bekerja part time. Dari kesimpulan kuesioner dapat dikatakan bahwa responden tidak bisa menahan diri bermain handphone/nonton tv, karenak sebagian aktivitas yang dilakukan untuk mengerjakan tugas menggunakan handphone / laptop. Jadi, disela mengerjakan tugas itulah mereka main game, atau menggunakan media sosial untuk chatting dengan temannya. (Lihat Gambar 6)

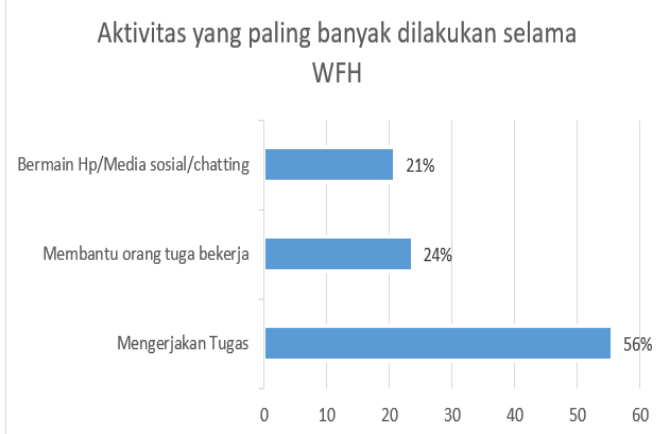

Gambar 6 Aktivitas yang paling banyak dilakukan selama WFH

Sumber data olahan penulis 2020

Proses penggunaan aplikasi classroom sebagai media belajar, siswa banyak memnggunakan Laptop, Hp, meminjam bahkan merental laptop/komputer

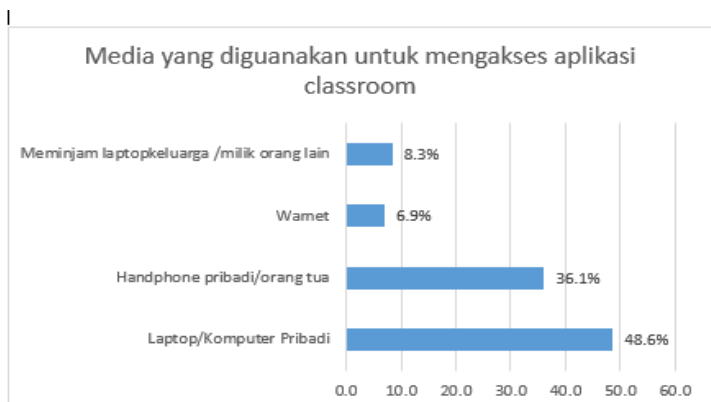

Gambar 7 Media yang digunakan untuk mengakses aplikasi classroom

Sumber data olahan penulis 2020

Penggunaan Hp dengan durasi waktu yang terlalu lama dan intensitas yang terlalu sering/ tinggi mengakibatkan mereka mengalami keluhan fisik paling banyak berupa badan pegal/pinggang sakit/tangan sakit sebesar 26,4\%, sakit kepala atau migraine(16,7\%), mata lelah/sakit/bengkak $(12,5 \%)$. (Lihat Gambar 8). 


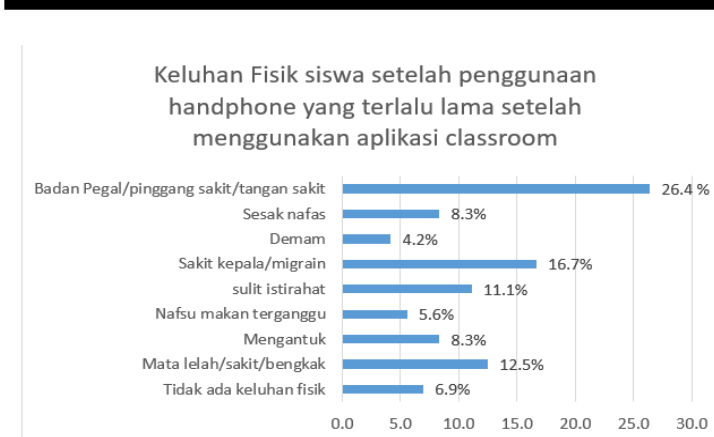

Gambar 8 Keluhan fisik setelah penggunaan aplikasi classroom Sumber data olahan penulis 2020

b. Penjabaran hasil tentang pembelajaran Daring mata pelajaran penjaskes

1) Model pembelajaran yang disukai siswa.

Hasil penelitian menggambarkan hanya $18 \%$ siswa yang menyukai model pembelajaran daring (online menggunakan aplikasi classroom), $33 \%$ siswa menyukai model pembelajaran blended (menggabungkan model pembelajaran tatap muka dan daring dan siswa nya $49 \%$ atau sebagian besar siswa lebih menyukai tatap muka dikelas ataupun dilapangan untuk pembelajaran olahraga/penjaskes.

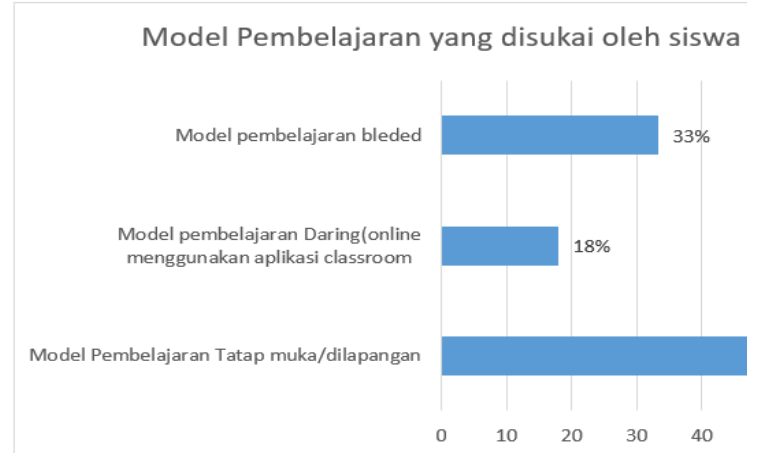

Gambar 9 Model pembelajaran yang disukai siswa

Sumber data olahan penulis 2020

Batasan ruang dan waktu semakin hilang dikarenalan Teknologi informasi dan telekomunikasi yang murah dan mudah untuk didapatkan tetap tidak menujukkan hasil yang bail. Dari hasil kuesioner didpaatkan data bahwanya harus ada keseimbangan antara pembelajaran tatap muka dan daring. Bahkan dapat dikatakan bahwa siswa lebih menyukai pembelajaran tatap muka.

2) Metode pembelajaran di classroom yang disukai siswa

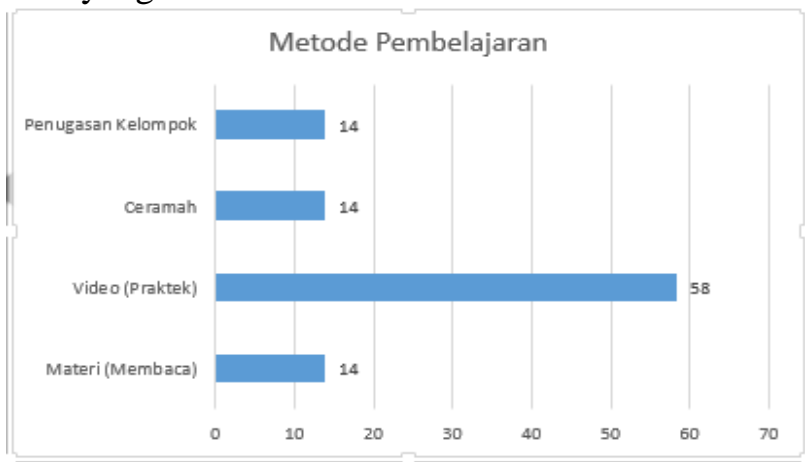

Gambar 10 Metode Pembelajaran di classroom yang disukai siswa

Sumber data olahan penulis 2020

3) Kendala yang dihadapi siswa selama menggunakan classroom

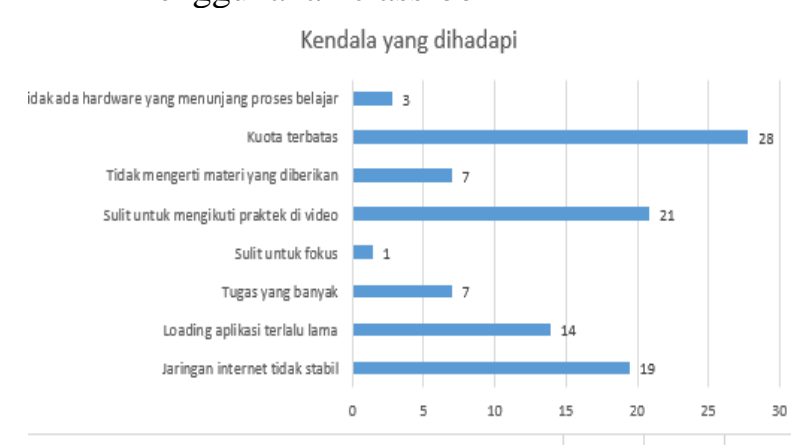

Gambar 11 Kendala yang dihadapi siswa selama menggunakan classroom Sumber data olahan penulis 2020

3. Uji prasarat analisis data

a. Uji Normalitas : yang dilakukan adalah asumsi klasik pendekatan OLS, Berdasarkan besaran nilainya (Kolmogorov-Smirnov adalah 0,888 dengan tingkat signifikansi $>0,05$ artinya terima Ho berarti residual data berdistribusi normal, pada sebaran normal-P Plot nya titik titik tersebut mendekati garis lurus, sehingga dapat 
disimpulkan bahwa residual berdistribusi normal.

b. Uji Multikolonieritas dilakukan untuk melihat kebebasan antar variable bebas, dari hasil perhitungannya ditketahu tidak ada nilai VIF >10 maka keputusannya yang diambil adalah Tolak Ho dan terima $\mathrm{Ha}$, kesimpulannya adalah antar variable bebas yaitu penggunaan classroom, waktu pembelajaran dan kondisi belajar tidak terdapat multikolinearitas.

c. Uji Heteroskedastisitas. Asumsinya adalah melakukan uji Glejser dan melihat sgrafik scatterplot. Sehingga didapatkan nilai variable dependennya yaitu nilai residual dan dependen variabelnya adalan Penggunaan goolge classroom, waktu pembelajaran, kondi belajar nilai significannya adala 1.00 artinya variable independent dalam model ini memiliki sebaran yag sama.

4. Uji Hipotesis

a. Uji Regresi Berganda (Efektivitas Penggunaan classroom terhadap kualitas pembelajaran) hasil persamaan regresi linear nya adalah : pada penelitian ini nilai koefisien regresi bertanda positif dan dapat diartikan bahwa terjadi pengaruh positif dari variabel penggunaan classroom (X1), Waktu pembelajaran (X2) dan Kondisi belajar (X3) terhadap kualitas pembelajaran (Y), dengan kata lain semakin tinggi nilai $\mathrm{X} 1, \mathrm{X} 2$, dan $\mathrm{X} 3$ maka akan berpengaruh langsung dengan nilai Y1. Pada hasil penelitian ini dpat dilihat bahwa nilai tertinggi hanya didpaatkan ileh $\mathrm{X} 1$ sehingga nilai $\mathrm{XI}$ memiliki nilai signifikansinya $(\mathrm{P}-$ Value) $<0,05$ (taraf signifikansi) sedangkan variabel lain meskipun berpengaruh positif tetapi tidak signifikan b. Uji ini digunakan untuk mengetahui apakah variabel bebas (penggunaan classroom (X1), Waktu pembelajaran (X2) dan Kondisi belajar (X3)) berpengaruh secara signifikan terhadap variabel terikat yaitu kualitas pembelajaran

(YKualitas_Pembelajaran). Hasil analisis regresi output diketahui nilai $\mathrm{F}$ 24,675

1) Hipotesis

Ho : Tidak ada pengaruh signifikan antara (X1), (X2) dan (X3) secara bersama-sama terhadap Kualitas Pembelajaran

(YKualitas_Pembelajaran)

Ha : Ada pengaruh secara signifikan antara (X1), (X2) dan (X3) secara bersama-sama terhadap Kualitas Pembelajaran (YKualitas_Pembelajaran)

2) Menentukan $F$ hitung dan $F$ tabel, diperoleh nilai Fhitung untuk model regresi sebesar 24,675. Untuk menentukan $\mathrm{F}$ tabel menggunakan tingkat keyakinan 95\%, a $=5 \%$, df1 (jumlah variabel-1) $=3$, dan df $2(n-k-1)$ $=72-3-1=68$ ( $\mathrm{n}$ adalah jumlah siswa dan $\mathrm{k}$ adalah jumlah variabel bebas), hasil diperoleh untuk $F$ tabel sebesar 5,76

\subsection{Pembahasan}

Setelah mendapatkan hasil penelitian dari menguji efektivitas pengaruh antara penggunaan classroom, waktu pembelajaran dan kondisi belajar terhadap terhadap kualitas pembelajaran daring / online dan hasil belajar siswa pada mata pelajaran penjaskes siswa kelas X.a dan X.B SMK Negeri 1 Indralaya Selatan. Sehingga dapat melihat seberapa efektif aplikasi google classroom terhadap mata pelajaran penjaskes dalam meningkatkan kualitas 
pembelajaran dan hasil belajar, adapun pembahasan nya akan diuraikan sebagai berikut:

1. Antara X1, X2 X3 terhadap Y1,

Analisis data dilakukan dengan menggunakan regresi linear berganda dapat diyatakan bawah Hal diterima dan H01 ditolak. Hal ini berarti aplikasi google classroom sangat efektif terhadap peningkatan kualitas pembelajaran mata pelajaran penjaskes kelas X.a dan X.b.

Nilai koefisien regresi menunjukan nilai $\mathrm{F}$ hitung $>\mathrm{F}$ tabel, yang berarti terdapat pengaruh signifikan secara bersama-sama antara variabel Penggunaan Aplikasi google classroom, waktu belajar, dan kondisi belajar terhadap kualitas pembelajaran sehingga dapat dikatakan efektif.

Pengujian hipotesis secara parsial menunjukan bahwa dari tiga variabel dalam penelitian ini hanya satu variabel yang berpengaruh terhadap kualitas pembelajaran yaitu variabel penggunaan google classroom. Variabel penggunaan google classroom menunjukan nilai $\mathrm{t}$ hitung $>\mathrm{t}$ tabel, maka terdapat pengaruh signifikan Penggunaan google classroom terhadap kualitas pembelajaran siswa kelas X.a dan X.b SMK Negeri 1 Indralaya Selatan. Adanya efektivitas terhadap penggunaan google classroom dikarenakan aplikasi ini memberikan berbagai kemudahan kepada siswa dalam memahami pelajaran. Peningkatan kualitas pembelajaran yang dimaksud di sini meliputi peningkatan baik pada proses kegiatan belajar mengajar atar guru dan siswa maupun pada hasil akhir perolehan nilai siswa terhadap ujian yang dilaksanakan.
2. Pengaruh kualitas pembelajaran terhadap hasil belajar Berdasarkan hasil analisis data dengan menggunakan regresi logistik ordinal menyatakan bahwa $\mathrm{Ha} 2$ diterima dan $\mathrm{H} 02$ ditolak. Artinya terdapat pengaruh kualitas pembelajaran secara simultan terhadap hasil belajar mata pelajaran penjaskes siswa kelas X.a dan X.B SMK Negeri 1 Indralaya Selatan. Hal tersebut sesuai dengan data perolehan wawancara dan observasi yang dilakukan peneliti, semakin baik kualitas pembelajaran yang diberikan oleh guru dan siswa dapat memahami pembelajaran tersebut maka akan semakin meningkat hasil belajar siswa sehingga hasil yang diperoleh menjadi lebih optimal.

\subsection{Keterbatasan peneliti}

Penelitian ini telah diusahakan dan dialkukan sesuai prosedur ilmiah, akan tetapi meiliki keterbatasan antara lain :

a. Peneliti tidak dapat menampilkan seluruh hasil penelitian (terutama uji prasyarat dan uji hipotesis) dalam bentuk gambar maupun tabel

b. Nilai yang dipakai hanya berdsarkan kebutuhan saja

c. Hanya menggunakan 3 vaeriabel saja dalam menentukan kualitas pembelajaran dan hasil belajar.

\section{KESIMPULAN}

Berdasarkan penelitian yang telah dilakukan dapat disimpulkan beberapa hal diantaranya adalah sebagai berikut: Penggunaan Aplikasi google classroom sangatlah efektif dan meliliki pengaruh positif terhadap kualitas pembelajaran pada mata pelajaran penjaskes siswa kelas X.a dan X.B SMK Negeri 1 Indralaya Selatan. Hal ini ditunjukan menggunakan regresi linear berganda diperoleh nilai r 0.947, Nilai Adjusted R2 sebesar 0.678, dan nilai t hitung 
$>\mathrm{t}$ Tabel $(2,457>2,145)$ dengan siginifikansi 0.063 (pengujian dua sisi). Dengan demikian semakin baik penggunaan google classroom maka akan semakin baik kualitas pembelajaran yang ada di kelas pada mata pelajaran penjaskes siswa kelas X.a dan X.B SMK Negeri 1 Indralaya Selatan. Yang tentunya akan berpengaruh positif terhadap kualitas pembelajaran dan tentunya akan meningkatkan hasil belajar siswa menjadi lebih optimal pada mata pelajaran penjaskes siswa kelas X.a dan X.B SMK Negeri 1 Indralaya Selatan Hal ini ditunjukan menggunakan regresi logisik ordinal diperoleh nilai R 2 (Nagelkerke) sebesar 0.746 , dan nilai estimate sebesar 0.892 yang dieksponensialkan menjadi 2.44 dengan signifikansi $0.016<0.05$.

\section{SARAN}

Saran dalam penelitian yaitu dengan mengetahui bahwa aplikasi google classroom sangat efektif dalam meningkatkan kualitas pembelajaran dan hasil belajar pada mata pelajaran penjaskes, maka siswa diharapkan dapat lebih mengoptimalkan penggunaan google classroom dalam pembelajaran sehingga dapat meningkatkan pemahaman terhadap materi dan memotivasi siswa untuk memperoleh kualitas belajar hasil belajar yang lebih baik.

\section{DAFTAR PUSTAKA}

[1] M. V. Domenico Cucinotta, "Who Declares COVID-19 a Pandemic," National Library Of Medicine, 2020.

[2] M. Mustakim, "Efektivitas Pembelajaran Daring Menggunakan Media Online Selama Pandemi Covid-19 Pada Mata Pelajaran Matematika," Al asma J. Islam. $E d u c$. , vol. 2, no. 1, p. 1, 2020, doi: 10.24252/asma.v2i1.13646.
[3]

S. R. C. Tri, "Pengaruh Work From Home (WFH) Terhadap Kinerja Guru SD Negeri Dengkek 01 Pati Selama Masa Pandemi Covid-19," EduPsyCouns J. Educ. Psychol. Couns., vol. 2, no. 1, pp. 424-437, 2020, [Online]. Available: https://ummaspul.e-

journal.id/Edupsycouns/article/view/ 500.

[4] N. S. Hanum, "Keefetifan e-learning sebagai media pembelajaran (studi evaluasi model pembelajaran elearning SMK Telkom Sandhy Putra Purwokerto)," J. Pendidik. Vokasi, vol. 3, no. 1, pp. 90-102, 2013, doi: 10.21831/jpv.v3i1.1584.

[5] A. B. Kusuma and W. Astuti, "Analisis Penerapan Media Pembelajaran Bahasa Arab Berbasis Aplikasi Google Classroom," $J$. Lahjah Arab., vol. 1, no. 1, pp. 6789, 2019.

[6] A. Ghofur, "Using Google Classroom on Inquiry Based Learning To Improve Students , Learning Participation," J. Penelit. Pendidik., vol. 10, no. 2, pp. 15031509, 2018, [Online]. Available: http://www.ejournal.stkippacitan.ac. id/index.php/jpp/article/download/2 26/302.

[7] S. A. Hapsari and H. Pamungkas, "Pemanfaatan Google Classroom Sebagai Media Pembelajaran Online Di Universitas Dian Nuswantoro," WACANA J. Ilm. Ilmu Komun., vol. 18, no. 2, pp. 225-233, 2019, doi: 10.32509/wacana.v18i2.924.

[8] E. Nurfalah, "Optimalisasi ELearning berbasis Virtual Class dengan Google Classroom sebagai Media Pembelajaran Fisika," Phys. Educ. Res. J., vol. 1, no. 1, p. 46, 2019, doi: 10.21580/perj.2019.1.1.3977. 
[9] A. (SMAN 1 L. Hardiyana, "Implementasi Google Classroom sebagai Alternatif dalam Meningkatkan Mutu Pembelajaran di Sekolah," Karya Tulis Ilmiah. pp. 13-23, 2015.

[10] O. Oludare Jethro, A. Moradeke Grace, and A. Kolawole Thomas, "ELearning and Its Effects on Teaching and Learning in a Global Age," Int. J. Acad. Res. Bus. Soc. Sci., vol. 2, no. 1, pp. 2222-6990, 2012.

[11] A. B. Hakim, "Efektifitas Penggunaan E-Learning Moodle , Google Classroom Dan Edmodo," vol. 2, pp. 1-6, 2016.

[12] H. H. Batubara, "Di Prodi Pgmi Uniska Muhammad Arsyad Al Banjari," Univ. Islam Kalimantan $M A B$, vol. 8, no. 1, pp. 40-50, 2016.

[13] M. P. Prof.Dr. Hamzah B.Uno, Model Pembelajaran (Mencipatakan Proses Belajar Mengajar yang Kreatif dan Efektif). Yogjakarta: Bumi Aksara, 2012.

[14] A. Z. Syaiful Bahri Djamarah, Strategi Belajar Mengajar. Jakarta: Rineka Cipta, 2006.

[15] I'anatut Thoifah, Statistika Pendidikan dan hipote Penelitian Kuantitatif, Cetakan sa. malang, 2015.

[16] S. Hidayat and dkk, "Pengaruh Pemberian Assessment Essay Terhadap Pencapaian Kompetensi Siswa Dalam Pembelajaran Fisika Menggunakan Pendekatan Ekspositori Dan Inkuiri Di Kelas XI IA SMA N 1 Kecamatan Suliki Kabupaten Lima Puluh Kota," $J$. Penelit. Pembelajaran Fis., vol. 1, pp. 1-14, 2012.

[17] A. M. Yusuf, Asesmen dan evaluasi pendidikan: pilar penyedia informasi dan kegiatan pengendalian mutu pendidikan. Jakarta:
Prenadamedia Group, 2015.

[18] R. Kriyantono, Teknik Praktis Riset Komunikasi. Jakarta: Kencana, 2006.

[19] I. Ghozali, Aplikasi Analisis Multivariete dengan Program IBM SPSS 23. Semarang: Undip, 2013.

[20] A. Sugiyono, Metode penelitian pendidikan: (pendekatan kuantitatif, kualitatif dan $R \quad n \quad D$. Jakarta: Alfabeta, 2008.

[21] S. Arikunto, No Title, Ed. Rev. V. Jakarta: Rineka Cipta 2011, 2011. 